\title{
Progressive Muscle Relaxation Effectiveness of the Blood Sugar Patients with Type 2 Diabetes
}

\author{
Nani Avianti, Desmaniarti Z., Hotma Rumahorbo \\ Department of Nursing Bandung Healthy Polytechnic of the Ministry of Health of the \\ Republic of Indonesia, Bandung, Indonesia \\ Email: naniavianti57@gmail.com
}

Received 24 February 2016; accepted 27 March 2016; published 30 March 2016

Copyright (C) 2016 by authors and Scientific Research Publishing Inc.

This work is licensed under the Creative Commons Attribution International License (CC BY). http://creativecommons.org/licenses/by/4.0/

(c) (i) Open Access

\section{Abstract}

Background: Diabetes Melilltus (DM) is one serious chronic illness. The proportion of incident type 2 diabetes is $95 \%$ of the population of DM in the world. The prevalence of DM in Indonesia showed an increase of $1.1 \%$ in 2007 to $2.1 \%$ of the population of DM in 2013, and the most cases are Type 2 Diabetes Mellitus. Management of blood sugar levels can be conducted of pharmacologic and nonpharmacologic. One of nonpharmacologic therapy is a complementary therapy. Progressive muscle relaxation is part of a of complementary therapy which is a mindbody therapy. Objective: This study aimed to measure the effectiveness of progressive muscle relaxation of the blood sugar levels of patients with type 2 diabetes. Materials and Methods: Quasi experiment with pre- and posttest randomized control group design, consisting of 48 samples, 24 samples 24 samples of the treatment group and the control group. Subjects treated group guided progressive muscle relaxation exercises 2 times a day for 3 consecutive days with a duration of 25 - 30 minutes in one workout. Subjects of the control group gave breathing exercises. Results: There were significant differences between the average blood sugar levels type 2 diabetes patients in the the treatment group and the control group, with $p$ value $=0.000$ $(p<0.05)$. Conclusion: The progressive muscle relaxation is effective to reduce blood sugar levels of patients with type 2 diabetes at Dr. Salamun Hospital and Advent Hospital in Bandung.

\section{Keywords}

Progressive Muscle Relaxation, Blood Sugar Levels, Type 2 Diabetes Mellitus 


\section{Introduction}

At this time Diabetes Mellitus becomes one chronic disease which causes death, disability and disease prevalence continues to increase. According to the International Diabetes Federation [1] the prevalence of the incidence of diabetes mellitus in 2012 amounted to 371 million of the DM population in the world, where the proportion of incidence of Type 2 diabetes mellitus is $95 \%$ of the population of DM in the world. WHO estimates that in 2030 Indonesia ranks -4 of the number of people with diabetes in the world after the United States, China and India [2]. The prevalence of DM in Indonesia showed an increase of 1.1\% in 2007 to 2.1\% in 2013 [3]. Most cases are type 2 diabetes which covers $90 \%$ of the population of DM [4]. In Type 2 diabetes, there are two major problems associated with insulin including insulin resistance and deficiency of insulin. The number of insulin receptors on the cell membrane is reduced at insulin resistance. This situation caused the amount of glucose entering the cells is reduced, while the production of glucose by the liver continues to increase, causing hyperglycemia in type 2 diabetes [5]. Primary treatment of type 2 diabetes is to lose weight because insulin resistance is associated with obesity. Exercise is an essential element also to raise the effectiveness of insulin. Oral hyperglycemic drug can be added if diet and exercise do not successfully control blood sugar levels [5]. According Soegondo there are five pillars of the management of DM in Indonesia: Diet, physical exercise, drugs that lower blood sugar levels, education and self-monitoring of blood sugar [6]. Education includes management stress to control blood sugar levels. As noted by Smeltzer and Bare that chronic hyperglycemia if not addressed will cause complications such as retinopathy, microangiopathy, macroangiopathy and gangrene [5]. This complication is lethal for diabetes; for example, termites can damage organs without any symptoms, so that diabetes mellitus is often called the "silent killer" [7]. Chronic hyperglycemia causes the patient to undergo treatment at the hospital for the management of blood sugar levels and complaints arising from diseases that accompany it; this situation often makes patients physical and mental stress; this can lead to increased blood sugar levels. In times of stress the body will release hormones such as cortisol, catecholamines, glucagon and growth hormone. All four of these hormones increase blood sugar levels and the amount of energy a lot more. When the increased cortisol secretion is in a stressful situation, therefore, as a nurse in addition to providing collaborative actions nurses can also help patients improve their ability to control blood sugar levels through progressive muscle relaxation. Relaxation training is needed to lower blood sugar levels, or suppress the secretion of cortisol, controlling negative emotions and controlling diet [8]. This study are type 2 DM patients with depression as a subject. Progressive muscle relaxation (PMR) mechanism can lower blood sugar levels in patients with type 2 diabetes are closely related to the stress experienced by the patient, either physical or psychological stress. Stressful can increased the secretion of stress hormones such as epinephrine, glucagon, cortisol at caused hyperglycemi [5]. Research Ghazavi et al. [9] showed that PMR given to patients with diabetes can lower HbA1C levels. The results of this study explain that PMR can lower blood sugar levels by raising the relaxed conditions. In this condition there is a change of nerve impulses in the afferent pathways to the brain where inhibition of activation becomes. Changes in these nerve impulses cause the juice to relax both physically and mentally, decreased heart rate, metabolic rate of the body to prevent an increase in blood sugar levels. Relaxation is a form of mind body therapy (therapy minds and muscles of the body) in complementary and alternative therapies (Complementary Alternative Therapy (CAM) [10] is the treatment of nonpharmacological which in its management based in the work of sympathetic and parasympathetic nerves. The stress response is a closed feedback path between the muscles and the mind [11]. Assessment of stressors result in muscle tension which sends stimulus to the brain and build a feedback path. The progressive muscle relaxation will inhibit the pathway by activating the parasympathetic nervous system works and manipulating the hypothalamus through the concentration of the mind to reinforce positive attitude, so the impulse stress on the hypothalamus reduced. According to Jacobson describes that progressive muscle relaxation of response to the tensions that led to a change in control of the autonomic nervous activity in the form of reduced function of oxygen, respiratory rate, pulse rate, muscle tension, blood pressure and alpha waves [12]. Progressive muscle relaxation exercise performed 20 - 30 minutes, once a day on a regular basis for one week. Some research suggests that non-pharmacological approaches include relaxation techniques is an intervention that can be performed on patients with diabetes mellitus [13]. According Dunnning of complementary therapies to benefit patients with DM can be improve reception conditions at this time, reduce stress, anxiety, depression, develop sustainable strategies to prevent stress [14]. He also explained that the advantage of progressive muscle relaxation improve metabolic control, lowering blood sugar, lowering catecholamines and autonomic nervous activity. After the relaxation of the patient will feel relaxed and comfortable condition, progressive relaxation can make the body and 
the mind becomes calm and relaxed [15]. Relaxation increase the secretion of endorphins and decreases the secretion of adrenal hormones, in addition to improving blood circulation, and reduce stress and anxiety caused by the emergence of a positive attitude due to increased brain function. Furthermore, we will control the balance of blood sugar and blood pressure [16]. Research Ghazavi et al., showed that the progressive relaxation and massage lowered HbA1C levels of type $1 \mathrm{DM}$ patients [9]. Khaviani et al. study showed that the relaxation exercise to lower blood sugar levels two hours postprandial with p value $<0.001$ [17]. Research Radarhonto et al. showed that there is a progressive relaxation effect on the blood sugar level of patients with type 2 diabetes [18]. While Mashudi study showed that the progressive muscle relaxation (PMR) is performed three times for one week to give a significant effect on blood sugar level of patients with diabetes mellitus [19]. He also explained that PMR will provide optimal results when performed with a duration of 25 - 30 minute for once session. This study aims to determine the effectiveness of progressive muscle relaxation of the blood sugar levels of patients with type 2 diabetes.

\section{Research Hypothesis}

The progressive muscle relaxation effectively lower blood sugar levels of patients with type 2 diabetes.

\section{Materials and Methods}

This research is a "quasy Experimental with pre and post test randomized control group design". Sample size of 48 is determined on the level of trust $0.05,24$ samples were divided Into experimental an control groups of 24 samples. The criteria for sample inclusion of the DMT2 patients were patients treated for the first time; patients with a depression within a range of scores of 8 - 21; patients with a blood glucose level of $\geq 160 \mathrm{mg} / \mathrm{dl}$; patients not currently treated with any anti depressants; patients with no breathing and musculoskeletal problems; patients who were able to read and write; patients who had no hearing impairments; and patients who had never been treated with progressive relaxation as well as those who were willing to join the training or exercice. This study has been approved by the ethical committee of health polytechnic republic of Indonesia's health ministry majoring in nursing bandung, with No: 64/KEPK-PKKB/6/2015. Informed consent was done after the patient agree to discussion on the benefits and steps of PMR. The research process begin by identifying patients with type 2 diabetes are first admitted to hospital with blood sugar levels equal and above $160 \mathrm{mg} / \mathrm{dl}$ at the two study sites. Further subjects are into 2 groups in order of acquisition where the subject was fisrt discovered (according to criteria) into the treatment group, and the second subject to a control group, and so on. After the $1^{\text {st }}$ blood glucose measurements with accu check (pre test), the treatment group given exercise intervention progressive muscle relaxation therapy with duration of 25 - 30 minutes in one workout, use the 14 movements of the body [20]. At the time of exercise PMR, subject tutored by researchers. For accuracy of the duration of exercise, the researchers use a timer. PMR exercises conducted over three consecutive days for 6 times every morning and evening, after the training program is completed, do the $4^{\text {th }}$ blood glucose measurements with accu check (post-test). Recently the subjects is also equipped with guide books progressive muscle relaxation exercises with the hope to be able to perform independently.

The collected data were processed and analyzed gradually form of univariate and bivariate analysis. Univariate analysis using frequency distribution and proportion, the mean standard deviation daan, while bivariate analysis using the Wilcoxon test for each group and Mann Whitney test to tell the difference between the measurement results in the treatment group and the control group.

\section{Result}

From Table 1, it can be concluded that the average age of respondents treatment groups of 59.1 years and the average age of the respondents in the control group was 61.1 years.

From Table 2 it can be concluded that the treatment group and the control group mostly of 20 respondents (83.3\%) were female and the remaining 4 respondents (16.7\%) were male.

From Table 3 it can be concluded that education in the treatment group more than half is 13 respondents (54.2\%) are primary school graduates. In the control group of less than half (33.3\%) graduated from yunior high school and (20.8\%) graduated from senior high school.

From Table 4 it can be concluded that the treatment group more than half of 15 respondents (62.5\%) did not 
Table 1. Distribution of respondents by age (in years).

\begin{tabular}{ccccc}
\hline Group & Mean & Median & SD & Min-Max \\
\hline Treatment $(\mathrm{n}=24)$ & 59.1 & 59 & 6.9 & $38-70$ \\
Control $(\mathrm{n}=24)$ & 61.1 & 63 & 7.0 & $41-70$ \\
\hline
\end{tabular}

Table 2. Distribution of respondents by sex.

\begin{tabular}{ccccc}
\hline \multirow{2}{*}{ Variable } & \multicolumn{2}{c}{ Treatment $(\mathrm{n}=24)$} & \multicolumn{2}{c}{ Control $(\mathrm{n}=24)$} \\
\cline { 2 - 5 } & $\mathrm{f}$ & $\%$ & $\mathrm{f}$ & $\%$ \\
\hline Gender & & & & 16.7 \\
Male & 4 & 16.7 & 4 & 83.3 \\
Female & 20 & 83.3 & 20 & 100 \\
Total & 24 & 100 & 24 & \\
\hline
\end{tabular}

Table 3. Distribution of respondents by education.

\begin{tabular}{ccccc}
\hline Variable & \multicolumn{2}{c}{ Treatment $(\mathrm{n}=24)$} & \multicolumn{2}{c}{ Control $(\mathrm{n}=24)$} \\
\cline { 2 - 5 } & $\mathrm{f}$ & $\mathrm{f}$ & 3 & 12.5 \\
\hline Do not complete primary & & & 6 & 25 \\
Graduated from primary school & 13 & 25 & 8 & 33.3 \\
Graduated from yunior high school & 6 & 12.5 & 5 & 20.8 \\
Graduated from senior high school & 3 & 8.3 & 2 & 8.3 \\
Bachelor degree & 2 & 100 & 24 & 100 \\
Total & 24 & & & \\
\hline
\end{tabular}

Table 4. Distribution of respondents by job.

\begin{tabular}{ccccc}
\hline Variable & \multicolumn{2}{c}{ Treatment $(\mathrm{n}=24)$} & \multicolumn{2}{c}{ Control $(\mathrm{n}=24)$} \\
\cline { 2 - 5 } & $\mathrm{f}$ & $\%$ & $\mathrm{f}$ & 75 \\
\hline Unemployment unfixed & 15 & 62.5 & 18 & 16.7 \\
Unemployment and fixed income (housewives) & 4 & 16.7 & 4 & 4.2 \\
Active and fixed income & 2 & 12.5 & 1 & 4.2 \\
Active and less predictable income & 3 & 100 & 24 & 100 \\
Total & 24 & & & \\
\hline
\end{tabular}

work and was not fixed income. While in the control group most of which is 18 respondents (75\%) did not work and was not fixed income.

Based on Table 5 above it can be concluded that the treatment group average KGD before progressive muscle relaxation was $262.00 \mathrm{mg} / \mathrm{dl}$ and average KGD after progressive muscle relaxation was $183.87 \mathrm{mg} / \mathrm{dl}$, whereas the control group average KGD before intervention was $151.41 \mathrm{mg} / \mathrm{dl}$, and average KGD after the intervention was $180 \mathrm{mg} / \mathrm{dl}$.

Table 6 shows that in the treatment group after the Wilcoxon signed rank test p value $=0.000(p<0.05)$, then there is a significant difference between the average KGD before to after the progressive muscle relaxation. In the control group after the Wilcoxon signed rank test $\mathrm{p}$ value $=0.000(p<0.05)$, meaning that there is a significant difference between the average KGD before to after the intervention.

Table 7 shows that after a Mann-Whitney test, the value of $p=0.000(p<0.05)$, meaning that there is a significant difference between the average gap KGD type 2 diabetes patients in the treatment group and the control group. 
Table 5. Average blood sugar levels (KGD) Patients with type 2 diabetes before and after progressive muscle relaxation between treatment group and control group.

\begin{tabular}{cccccc}
\hline Variable & Group & Mean & Median & SD & Min-Max \\
\hline Blood Sugar & Treatment (n= 24) & & & & $140-528$ \\
& Before & 262.00 & 239.00 & 100.08 & $97-288$ \\
After & 183.87 & 163.50 & 61.48 & $140-400$ \\
Control (n= 24) & & & 15.62 & $146-342$ \\
Before & 151.41 & 146.00 & 46.31 & 162.00 \\
After & 180.00 & & & \\
\hline
\end{tabular}

Table 6. Results analysis of average blood sugar patients with type 2 diabetes before and after progressive muscle relaxation between treatment group and control group.

\begin{tabular}{ccccc}
\hline Variable & Group & Mean & SD & \\
\hline Blood Sugar & Treatment $(\mathrm{n}=24)$ & & & 0.000 \\
Before & 262.00 & 60.08 & 61.48 \\
After & 183.87 & 66.48 & 0.000 \\
Mean difference & 78.12 & & 15.62 \\
Control (n = 24) & & 46.3 & 43.78 \\
Before & 151.4 & 180.0 & -28.58 & \\
\hline
\end{tabular}

Table 7. Difference average blood sugar levels after intervention in patients with type 2 diabetes treatment group and control group.

\begin{tabular}{ccccc}
\hline Variable & Group & Mean difference & SD & $p$ Value \\
\hline \multirow{2}{*}{ Blood Sugar } & Treatment $(\mathrm{n}=24)$ & 78.12 & 66.48 & 0.000 \\
& Control $(\mathrm{n}=24)$ & -28.58 & 43.78 & \\
\hline
\end{tabular}

\section{Discussion}

Blood sugar levels can vary for each patient with type 2 diabetes, it is due to physical or emotional stress conditions are different, someone has a different response to the stress experienced. Fluctuating emotional state associated with different abilities of patients with type 2 diabetes in a defense against stress. Under conditions of emotional stress the body will release hormones that can increase blood sugar levels. Some research indicates that emotional stress associated with the secretion of cortisol, catecholamines, glucagon and growth hormone [17]. All four of these hormones increase blood sugar levels and a greater amount of energy (glucose and lipids) more for the cells, as the body's response to stress. These conditions will be exacerbated if patients with type 2 diabetes are not able to manage with good diet and exercise/sports regularly. Some research suggests that non-pharmacological approaches include relaxation techniques is an intervention, which can be performed on patients with diabetes mellitus [13]. Progressive muscle relaxation is one of the non-pharmacological approach that allows the patient to control the body's response to stress [21]. Based on the results shown in Table 5 the previous section, the results of the univariate analysis in the treatment group before the progressive muscle relaxation has a minimum value of random blood glucose levels of $140 \mathrm{mg} / \mathrm{dl}$ and a maximum value of $528 \mathrm{mg} / \mathrm{dl}$. This condition is unchanged after progressive muscle relaxation 2 times a day for 3 consecutive days with a duration of 25 - 30 minutes at a time, the value of at least $97 \mathrm{mg} / \mathrm{dl}$ and a maximum value of $288 \mathrm{mg} / \mathrm{dl}$. In the control group before the relaxation breathing 
has a minimum value of random blood glucose levels of $140 \mathrm{mg} / \mathrm{dl}$ and a maximum value of $400 \mathrm{mg} / \mathrm{dl}$, after the relaxation breathing minimum value of $146 \mathrm{mg} / \mathrm{dl}$ and a maximum value of $342 \mathrm{mg} / \mathrm{dl}$. Bivariate analysis is then performed to determine the difference between the average blood sugar levels as before and after progressive muscle relaxation in the treatment group and the average blood sugar levels before and after relaxation while breathing in the control group. Bivariate analysis was also conducted to determine differences in the average difference in blood sugar levels after progressive muscle relaxation during and after the relaxation breathing (in the control group). The results of the bivariate analysis in Table 6 in previous sections, showed that the treatment group and the control group there were significant differences between the average KGD as before to after the intervention with $p$ value $=0.000(p<0.05)$, but the big difference from the mean, it can be concluded that the group given the progressive muscle relaxation better at lowering blood sugar levels of patients with type 2 diabetes. Subsequently bivariate analysis was conducted to determine differences in the average difference in blood sugar levels after the intervention between the treatment group and the control group. The results of the analysis in Table 7 in the previous section shows that the average difference in blood sugar levels after progressive muscle relaxation was $78.12 \mathrm{mg} / \mathrm{dl}$, and the average difference after the relaxation breathing is $-28.58 \mathrm{mg} / \mathrm{dl}$. After the Mann-Whitney test, the value of $p=0.000(p<0.05)$, meaning that there is a significant difference between the average gap KGD as type 2 diabetes patients in the treatment group and the control group. The results showed that the progressive relaxation is effective in lowering blood sugar when patients with type 2 diabetes. The results are consistent with research Winata et al. [22], Radarhonto et al. [18] and research Mashudi [19] that Progressive Muscle Relaxation (PMR) can lower blood sugar levels of patients with type 2 diabetes. Other studies show similar results, namely research Ghazavi et al. [9] showed that he progressive relaxation and massage lowered HbA1C levels of patients with diabetes mellitus type 1. The results are also consistent with research Khaviani et al. [17] showed that the relaxation exercise to lower blood sugar levels two hours postprandial. Research Hasaini A also support the conclusion that this research through progressive muscle relaxation can lower blood sugar levels ( $p$ value $<0.05)$ [23].

The mechanism of progressive muscle relaxation can lower blood sugar levels in diabetes patients is closely related to the physical and psychologist stress experienced by patients. During stress hormones trigger increased blood sugar levels such as epinephrine, cortisol, glucagon, kotrikosteroid will increase. In addition, the events of the life of patients with type 2 diabetes are full of stress is associated with poor treatment of patients with type 2 diabetes such as diet, exercise, and medication use [6]. According to Jacobson in Soewondo , the tension has to do with decreasing muscle fibers, while opponents of the tension is the absence of contractions [24]. Jacobson found that the tense and relax muscle groups 16 and distinguish sensations of tension and relax, one can eliminate muscle contraction and experiencing a sense of relaxation [24]. The relaxed state induced by progressive muscle relaxation resulted in changes in the afferent pathways of nerve impulses to the brain which causes the activation of becoming inhibition, occurred activation of the parasympathetic nervous system give rise to a serene feeling of physical and mental decline; heart rate, body's metabolic rate which in turn will lower blood sugar levels. Progressive muscle relaxation exercise done regularly (2 times a day), with a duration of one 30-minute exercise can support the body's activity and can further enhance the uptake of blood sugar by the tissue or cell. This was confirmed by Soewondo progressive relaxation impact on physiological responses and mental changes simultaneously, physiologically progressive muscle relaxation can lower blood pressure, reduce the frequency of the heart, reducing the need for oxygen, the brain will receive the optimal oxygen supply [24]. This condition causes the adrenal glands work becomes stable, the impact on blood sugar levels drop. Besides, movement of tense and relax the muscles bunch synonymous with physical exercise, according to researchers assumption when this activity is done correctly and regularly can increase the uptake of glucose by cells. With increasing intensity and duration of exercise, carbohydrate breakdown occurs more, so that the patient's blood sugar levels close to normal can DMPT2 or stable.

\section{Conclusion}

The conclusion of this study were: 1 ) There are significant differences the average blood sugar levels of patients with type 2 diabetes before and after progressive relaxation between the treatment group and the control group; 2) there are significant differences the average difference in blood sugar levels of patients with type 2 diabetes after progressive relaxation in the treatment group and the control group; 3) progressive relaxation is effective to reduce blood sugar levels of patients with type 2 diabetes. 


\section{Acknowledgements}

The writers would like to express their gratitude to the Director of Bandung Health Polytechnic of the Ministry of Health of the Republic of Indonesia and the Directors of Dr. Salamun Hospital and Advent Hospital in Bandung for the support. Our sincere thanks are also due to the whole research subjects for their participation in this research.

\section{References}

[1] International Diabetes Federation (IDF) http://idf.org

[2] WHO (2006) Prevention of Blindness from Diabetes Mellitus. http://www.WHO.int/blindness/preventionofblindnessfrmdiabetes

[3] Beever, S. (2006) New Type 2 Diabettes Cases Have Doubled in 30th: Health Reporter. http://www.medicinet.com

[4] Depertemen Kesehatan RI (2008) Jakarta: DepKes RI. Laporan Hasil Riset Kesehatan Dasar Indonesia tahun 2007.

[5] Smeltzer and Bare (2004) Medical Surgical Nursing. 10th Edition, Lippincott Williams \&Wilkins.

[6] Soegondo, S. (2005) Penatalaksanaan Diabetes Mellitus Terpadu. Medicine Faculty University of Indonesia, Jakarta.

[7] Nurahmani Ulfah (2012) Stop! Diabetes Mellitus. Familia, Yogyakarta.

[8] Goldenston, D., Kovacs, M. and Obrosky, D.(1995) A Longitudinal Study of Life Events and Metabolic Control among Youth with Insulin-Dependent Diabetes Mellitus. Health Psychology, 14, 409-414. http://dx.doi.org/10.1037/0278-6133.14.5.409

[9] Ghazavi, Z., Talakood, S., Abdeyaz, Z., Attari, A. and Joazi, M. (2007) Effects of Massage Therapy and Muscle Relaxation on Glycosylated Hemoglobin in Diabetic Children. http://dennyhendrata.wordpress.com/2/007/07/30/stres-dan-sistem-imuntubuh-suatu-pendekatan-psikoneuroimunologi$\underline{21}$

[10] Moyad, M. and Hawks, J.H. (2009) Complementary and Alternative Therapies. In: Dalam Black, J.M. and Hawk, J.H., Eds., Medical Surgical Nursing: Clinical Management For Positive Outcomes, 8th Edition, Elsevier Saunders.

[11] Snyder, M. and Linquist, R. (2002) Complementary Alternative Therapies in Nursing. 4th Edition, Springer Publishing Company, New York.

[12] Davis, M., Eshelman, E.R. and Matthew, M. (1995) Panduan Relaksasi dan Reduksi Stres. Edisi III, Alih Bahasa, Keliat, B.A., Hamid, A.Y., EGC, Jakarta.

[13] Dorbyk (2007) Relaxation on Diabetes Mellitus. University of North Carolina at Charlotte, Charlotte. http://www.psych.uncc.edu

[14] Dunning, T. (2003) Care of People with Diabetes: A Manual Nursing Practice. Blackwell Puslishing, Melbourne. http://dx.doi.org/10.1002/9780470774649

[15] Potter, P.A. and Perry, A.G. (2005) Buku Ajar Fundamental Keperawatan: Konsep, Proses, dan Praktik. Edisi 4, Volume 1, Alih Bahasa, Asih, Y., dkk. EGC, Jakarta.

[16] Mcgrady, A. (2010) The Effects of Biofeedback in Diabetes and Essential Hypertention. Clevelend Clinic Journal of Medicine, 77, 68-71. http://dx.doi.org/10.3949/ccjm.77.s3.12

[17] Khaviani, M., Bahoosh, N., Azima, S., Asadi, N., Sharif, F. and Sayadi, M. (2014) The Effect of Relaxation on Blood Sugar and Blood Pressure Changes of Women with Gestational Diabetes: A Randomized Control Trial. Iranian Journal of Diabetes and Obesity, 6, 14.

[18] Radarhonto, M., Imron, M. and Apriatmoko, R. (2015) Perbedaan Kadar Gula Darah Sebelum dan Setelah Diberikan Progressive Muscle Relaxation Di Desa Layangan Kabupaten Semarang. http://perpusnwu.web.id/karyailmiah/documents14506.pdf

[19] Mashudi (2011) Pengaruh Progressive Muscle Relaxation terhadap kadar gula darah pasien diabetes tipe 2 di Rumah Sakit Umum Daerah Raden Mattaher Jambi. http://lontar/ui.ac.id

[20] Psikologi Zone. Langkah-langkah Relaksasi Otot Progresif. Acsessed August 2014. http://www.psikologizone.com

[21] Kozier, E. and Breman, S. (2004) Buku Ajar Fundamental Keperawatan Konsep, Proses dan Praktik. Alih bahasa, Wahyuningsih dkk. EGC, Jakarta.

[22] Winata, I.W., Achjar, K.A.H. and Suastana, I.N. (2015) Keperawatan Jiwa Komunitas dan Managemen, 2.

[23] Hasaini, A. (2015) Efektifitas Progressive Muscle Relaxation (PMR) terhadap Kadar Glukosa Darah pada kelompok penderita diabetes mellitus tipe 2 di Puskesmas Martapura. Caring Journal, 2, 16-27. http://journal.stikes-mb.ac.id/index.php/caring/article/.../17

[24] Soewondo, S. (2012) Stres, Managemen Stres dan Relaksasi Progresif. LPSP3UI. 